International Journal of Plant \& Soil Science
$7(4):$ 220-227, 2015; Article no.IJPSS.2015.148
ISSN: 2320-7035
SCIENCEDOMAIN international
wWw.Sciencedomain.org

\title{
Allelopathic Effects of Aqueous Extracts of Ricinus communis L. on the Germination of Six Cultivated Species
}

\author{
Ezzeddine Saadaoui ${ }^{1}$, José J. Martín ${ }^{2}$, Naziha Ghazel ${ }^{1}$, Chokri Ben Romdhane ${ }^{1}$, \\ Nouman Massoudi ${ }^{3}$ and Emilio Cervantes ${ }^{2 *}$ \\ ${ }^{1}$ Regional Station of Gabes, Laboratory GVRF, INRGREF, University of Carthage, Tunisia. \\ ${ }^{2}$ IRNASA-CSIC, Apartado 2576 Salamanca, Spain. \\ ${ }^{3}$ Regional Commission for Agricultural Development, Gabes, Tunisia.
}

This work was carried out in collaboration between all authors. Author ES designed the experiments, obtained and interpreted the results. Authors NG, NM and CBR collected the plants, obtained the extracts and contributed to the development of experiments. Authors JJM and EC contributed to the analysis and elaboration of results. All authors read and approved the final manuscript.
Article Information
DOI: 10.9734/IJPSS/2015/16483 Editor(s):
(1) Fatemeh Nejatzadeh, Department of Horticulture, Faculty of Agriculture, Khoy Branch, Islamic Azad University, Iran.
Reviewers:
(1) Anonymous, University of Malaysia, Malaysia. (2) Anonymous, Federal University of Technology, Nigeria. (3) Musharaf Khan, Department of Botany, University of Peshawar, Pakistan. Complete Peer review History: http://www.sciencedomain.org/review-history. php?iid=1096\&id=24\&aid=9317

Short Research Article

Received $3^{\text {rd }}$ February 2015 Accepted $2^{\text {nd }}$ March 2015 Published $19^{\text {th }}$ May 2015

ABSTRACT

Aims: The effect of aqueous extracts of castor bean (Ricinus communis L.) On the germination of six cultivated crops was investigated.

Study Design: Samples of $R$. communis were harvested from the region of Gabès (south of Tunisia) and tested at laboratory on crops seeds.

Place and Duration of Study: Regional station of Gabès- National Institute of Research in Rural Engineering, Waters and Forests - Tunisia, between October and December 2014.

Methodology: Extracts were obtained after an incubation of $9 \mathrm{~g}$ of dry plant material (powder) in $100 \mathrm{ml}$ distilled water during 48 hours at $60^{\circ} \mathrm{C}$. The extraction was made from five parts of $R$. communis (root, twig, leaf, seed and pericarp) and used in germination tests.

Results and Conclusion: Results showed two types of behavior: the aqueous extracts of root,

*Corresponding author: E-mail: ecervant@usal.es; 
twig, and seed had a low effect of inhibition for all studied species. The aqueous extracts of leaf and pericarp had a high effect of inhibition. C. olitorius is the most tolerant species; its germination rate is $99,99,97,96,69.5$ and $53.5 \%$ for aqueous extracts of root, twig, seed, leaf and pericarp respectively. L. culinaris is the most sensitive species; its rate of germination is $97,68.5,44,3$ and $0 \%$ for aqueous extracts of root, twig, seed, leaf and pericarp respectively. Leaf and pericarp aqueous extracts are the most inhibitive of germination resulting in germination rates lower than $16.5 \%$ for all studied species, except for C. olitorius, its germination rate is 69.5 and $53.5 \%$ with pericarp and leaf extract respectively. The aqueous extracts of $R$. communis inhibited root length in all studied species, essentially with the aqueous extracts of leaf and pericarp. These two parts of $R$. communis showed high allelopathy effect in percentage of germination and root length for all studied species.

Keywords: Allelopathy; Ricinus communis; aqueous extract; germination; root length; cultivated species.

\section{INTRODUCTION}

Some plants may inhibit germination, emergence and subsequent growth of other plants by exuding toxic substances. These substances are called allelopathic chemicals or allelochemicals and the process is called allelopathy. This phenomenon can be understood as the ability of different plant parts to inhibit or stimulate growth of other plants in the environment by exuding chemicals [1]. Natural products identified as allelochemicals represent a myriad of compounds and their chemical nature and groups have been already reported in many instances. However, phenolic compounds are the major group repeatedly reported and successfully detected and isolated from plants or soil [2,3]. Free phenolic compounds may accumulate in rhizosphere soils, especially in soils flooded with vegetable waste waters, thereby influencing the accumulation and availability of soil nutrients and rates of nutrient cycling, which both ultimately affect plant growth [2]. The analysis of effect of the water extracts of a species on the germination of other species is a method to estimate allelopathy in the laboratory.

Ricinus communis L. (Euphorbiaceae) is originally native to northeastern Africa and the Middle East. It has escaped cultivation and become naturalized as a weed almost everywhere in the world under tropical or subtropical climate [4]. R. communis is one of the oldest drugs known to man. The first mention of it as a laxative can be found in 3500 year-old Ancient Egyptian papyrus scrolls [5]. Ranging from cool temperate moist to wet through tropical desert to wet forest life zones, castor bean is reported to tolerate annual precipitation of 2.0 to $42.9 \mathrm{dm}$ annual temperature of 7.0 to $27.8^{\circ} \mathrm{C}$ and
$\mathrm{pH}$ of 4.5 to 8.3. It grows best where temperatures are rather high throughout the season, but seed may fail to set above $38^{\circ} \mathrm{C}$ for an extended period. Plant requires $140-180$ day growing season and is readily killed by frost [4]. Castor bean is a hardy crop, easy to establish on the field, resistant to drought, tolerate different types of soil even marginal soil [6]. R. communis was naturalized in Tunisia; it exists in spontaneous state, its distribution is from the North to the South, it occupies marginal soils, urban areas and agricultural land. $R$. communis $(2 n=20)$ is characterized by low morphological diversity; the diversity analyze of 12 Iranian accessions showed low genetic diversity of this species [7]. The low observed heterozygosity values suggest the predominance of autogamy in this species, which is known to have a mixed mating system, being both self- and crosspollinated by wind [8].

$R$. communis is an oilseed crop; it is primarily of economic interest as a source of castor oil, used for the production of high-quality lubricants because of its high proportion of the unusual fatty acid ricinoleic acid [9]. The seeds of castor bean contain more than $45 \%$ oil with high content in biodiesel (86 to 91\%) [10,11,12]. Yields comprised between 2242 and $3363 \mathrm{~kg}$ seeds per hectare and $350-900 \mathrm{~kg}$ oil per hectare were obtained $[6,12]$. $R$. communis contain chemical compounds like Ricin A, B and $C$ which have antitumor action, as well as alkaloids (ricinine) and glycosides which may be useful for various anti-inflammatory, analgesic, antipyretic, cardiotonic and antiasthmatic formulations [13]. The seeds contain 2.8-3\% toxic substances, in amount sufficient to produce lethal effects with 2.5-20 seeds. The principal toxin is the albumin, ricin; whose presence poses a problem for castor bean as a widely cultivated 
oilseed crop. However, the plant produces antigenic or immunizing activity, producing in small doses an antitoxin analogous to that produced against bacteria [4,9]. The plant possess beneficial effects such as antioxidant, antihistaminic, anti-asthmatic, antiulcer, immunomodulatory, anti-inflammatory, insecticidal, larvicidal and antiviral properties $[14,15,16,17$, 18]. Essential oils of $R$. communis contain $\beta$ thujone $(31.71 \%)$, 1,8-cinole $(30.98 \%)$, a-pinene $(16.88 \%)$, camphor $(12.98 \%)$ and camphene $(7.48 \%)$ and high antioxidant activity of the essential oil was observed [19]. Also, antimicrobial and anticarcinogenic properties of the essential oil have been showed [20]. Castor bean leaves are used in preparing long acting biocide compounds which are safe and stable and can completely control pests such as mosquitoes, flies, cockroaches, ants, fleas and lice in 24 hours. The leaves have insecticidal properties [4]. R. communis had high allelopathic effect on the germination and the growth of other species $[3,21,22,23,24]$. At concentration of 300$\mathrm{mg} \mathrm{DW}$ equivalent extract $/ \mathrm{mL}, R$. communis water extract completely inhibited the germination of cress and barnyard grass, and the seedling growth of cress, lettuce, Italian ryegrass, and barnyard grass [25].

In this study we investigated the allelopathic effect of root, twig, leaf, seed and pericarp water extract of $R$. communis on the germination and root growth of six cultivated species: Corchorus olitorius, $H$. vulgare, C. arietinum, $M$. sativa, $T$. foenum-graecum and $L$. culinaris

\section{MATERIALS AND METHODS}

Give adequate information to allow the experiment to be reproduced. Already published methods should be mentioned with references. Significant modifications of published methods and new methods should be described in detail. This section will include sub-sections. Tables \& figures should be placed inside the text. Tables and figures should be presented as per their appearance in the text. It is suggested that the discussion about the tables and figures should appear in the text before the appearance of the respective tables and figures. No tables or figures should be given without discussion or reference inside the text.

Tables should be explanatory enough to be understandable without any text reference. Double spacing should be maintained throughout the table, including table headings and footnotes.
Table headings should be placed above the table. Footnotes should be placed below the table with superscript lowercase letters.

Each figure should have a caption. The caption should be concise and typed separately, not on the figure area. Figures should be selfexplanatory. Information presented in the figure should not be repeated in the table. All symbols and abbreviations used in the illustrations should be defined clearly. Figure legends should be given below the figures.

\subsection{Sample Collection and Extraction}

Leaves, twigs, roots, seeds and pericarps of castor bean (Ricinus communis) were collected from spontaneous plants in Gabes (South of Tunisia; $33^{\circ} 53^{\prime} \mathrm{N}$ and $10^{\circ} 07^{\prime} \mathrm{E}$ ). The aqueous extracts were prepared from dried plant material ground in powder form. Nine grams of powered material were added to $100 \mathrm{ml}$ distilled water and incubated at $60^{\circ}$ for $48 \mathrm{~h}$. The extracts were filtered with filter paper. Aqueous solutions of $9 \%$ were obtained for each part of the plant. The methodology of extraction is similar to other authors $[26,27,28]$.

\subsection{Germination Test and Root Length}

The seeds were thoroughly washed with distilled water and surface sterilized with sodium hypochlorite (12\%) for 2-3 minutes. Fifty seeds were placed in each sterilized Petri dish of 90 $\mathrm{mm}$ diameter and $15 \mathrm{~mm}$ height, and irrigated with $2 \mathrm{ml}$ of water extracts (leaves, twigs, roots, seeds and pericarps) at $28^{\circ} \mathrm{C}$. The control was treated with $2 \mathrm{ml}$ distilled water. Each treatment had four replicates. Analyzed seeds belong to six cultivated species: barley (Hordeum vulgare), alfalfa (Medicago sativa), jute (Corchorus olitorius), fenugreek (Trigonella foenumgraecum), lentil (Lens culinaris) and chickpea (Cicer arietinum). Every day, seed germination was investigated. Three days after germination, root length was measured. Data are given as rate of germination (\%) and root length $(\mathrm{mm})$.

\subsection{Statistical Analysis}

Analysis of variance (ANOVA) and the differences between the parameters were evaluated by Student-Newman-Keuls test. Two way ANOVA (UNIANOVA) was conducted to see whether there is an interaction between species and origin of extracts (plant organ) in the parameters tested. Differences were considered 
when $P=.05$. Software used is XLSAT(2012) and SPSS 21.

\section{RESULTS AND DISCUSSION}

\subsection{Rate of Germination}

The effect of aqueous extract of $R$. communis varies according plant parts. In general, high inhibitory effect on germination of all studied species was observed with leaf and pericarp water extract and low inhibitory effect was reported with root, seed and twig aqueous extract (Figs. 1-6). Nevertheless, the response was different depending on the species $(P<.05$ in the UNIANOVA test). The lowest germination percentage was registered for five species treated with leaf water extract: $H$. vulgare, $C$. arietinum, $M$. sativa, $T$. foenum-graecum and $L$. culinaris; its germination rate varied between 3 and $16.25 \%$ (Figs. 1-5). Highest tolerance to allelopathic effect of leaf water extract was observed only with $C$. olitorius, its germination percentage is $53.5 \%$ (Fig. 6). A similar result was obtained with pericarp aqueous extract: low tolerance was observed for five species, with germination percentages ranging between $0 \%$ for $L$. culinaris and $15.5 \%$ for $H$. vulgare (Figs. 1$5)$. High tolerance was observed for $C$. olitorius treated with pericarp water extract; its germination percentage is $69.5 \%$ (Fig. 6). Twig water extract had a significant inhibitory effect on the germination of three species: $T$. foenumgraecum, $H$. vulgare, $M$. sativa, and $L$. culinaris, with germination percentages of $81,64,62.5$ and $44 \%$ respectively (Figs. 1, 2, 3 and 5). Finally, seed and root water extract had a significant inhibition only for $H$. vulgare and $L$. culinaris (Figs. 2 and 3). The two last species had low tolerance to allelopathic effect of all $R$. communis organs.

This result was observed with others species; inhibitory effect of leaf extract of castor bean on seed germination of lentil was registered [23]. Seyyedi et al. [22] showed high inhibitory effect of aqueous extracts of root, stem, leaf and whole plant of $R$. communis on germination of dodder (Cuscuta compestris). Also, aqueous extract of $R$. communis $(5 \%)$ has higher allelopathic inhibition on the germination of Convolvulus arvensis and Amaranthus retroflexus than aqueous extract of Crocus sativus and Sorghum vulgar [21,24]. C. olitorius is the most tolerant species for aqueous extracts of all $R$. communis parts; this tolerance was observed with aqueous extracts of other species: Eucalyptus occidentalis, Acacia ampliceps and Prosopis juliflora [28].

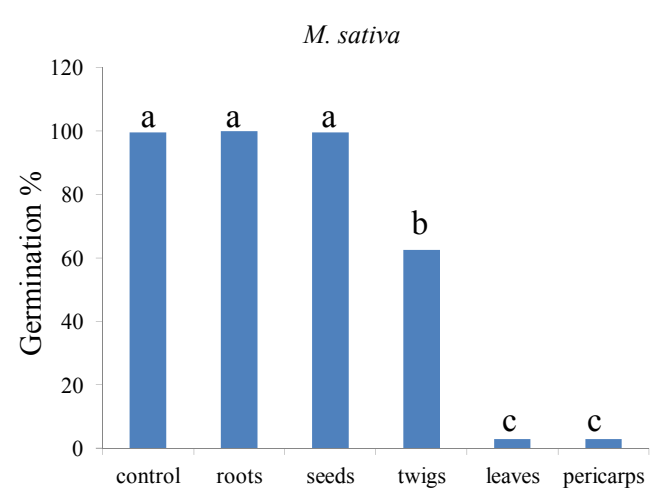

Fig. 1. Effects of aqueous extract of $R$. communis tissues on the germination of M. sativa

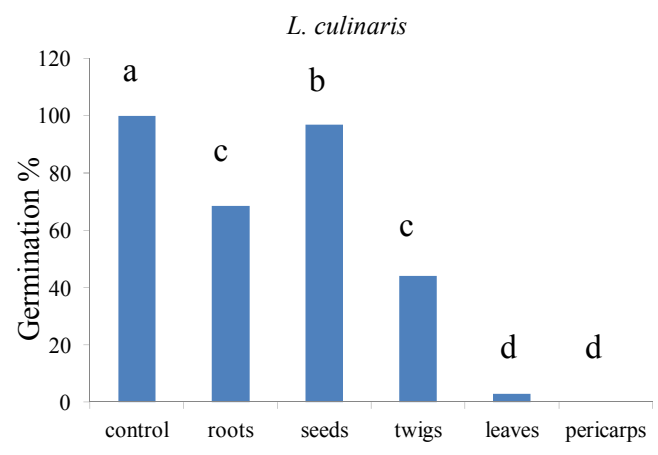

Fig. 2. Effects of aqueous extract of $R$. communis tissues on the germination of L. culinaris

\subsection{Root Lenght}

Significant difference was registered between treatments as well as for the interaction between treatment and species. The reduction percentage was between $48 \%$ for $C$. olitorius and $95.9 \%$ for T. foenum-graecum (Table 1). For all treated species, the lower inhibition was observed with aqueous extract of root (Table 1). Leaf and pericarp water extracts had the highest inhibitory effect on the growth of roots of the six studied species (the percentage of reduction was over $89.5 \%)$.

Water extracts had inhibitory effect on the root growth of the six studied species; this effect was registered by other authors. Leaf extract of castor bean inhibited growth of lentil roots [23]. Also, 
water extracts of Eucalyptus occidentalis, Acacia ampliceps and Prosopis juliflora inhibit root growth of $H$. vulgare, $M$. sativa and $C$. olitorius [28]. For C. arietinum, inhibitory effect of aqueous leaf extracts of Ficus infectoria, Emblica officinalis and Acacia leucophloea was much pronounced in root development than seed germination [29].

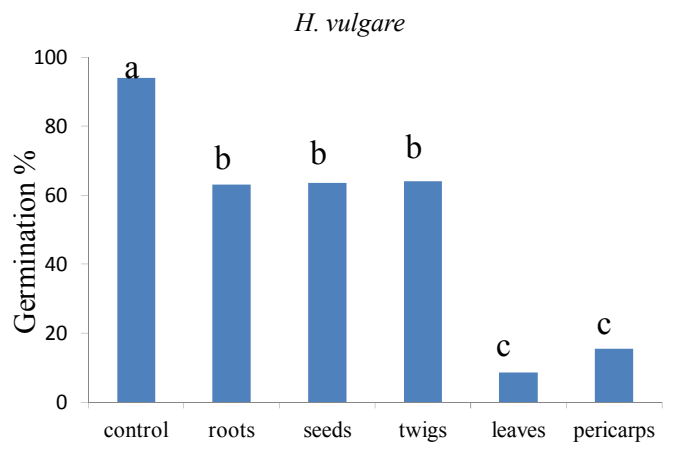

Fig. 3. Effects of aqueous extract of $R$. communis tissues on the germination of $H$. vulgare

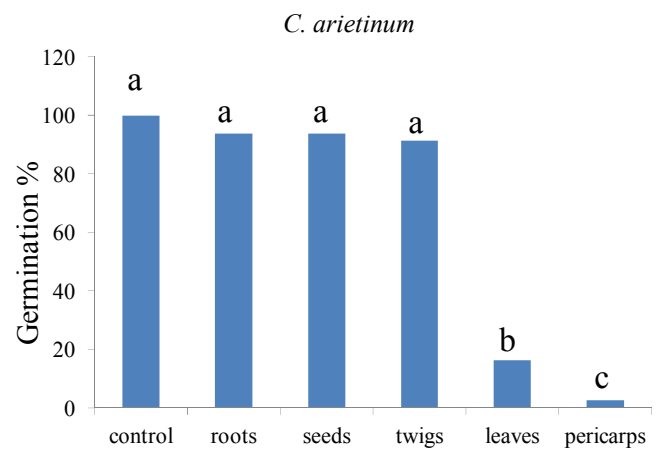

Fig. 4. Effects of aqueous extract of $R$. communis tissues on the germination of $C$. arietinum

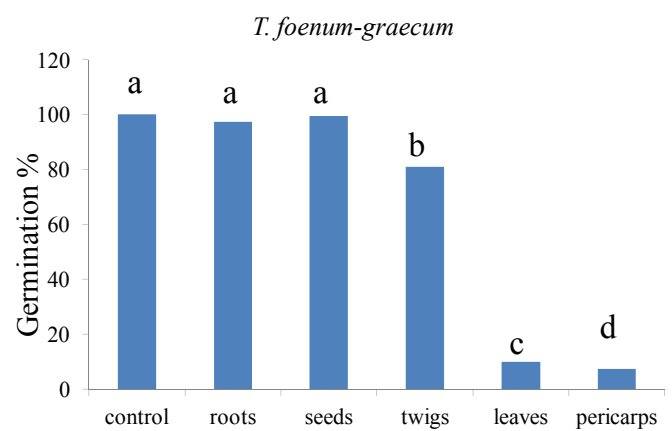

Fig. 5. Effects of aqueous extract of $R$. communis tissues on the germination of $T$. foenum-graecum

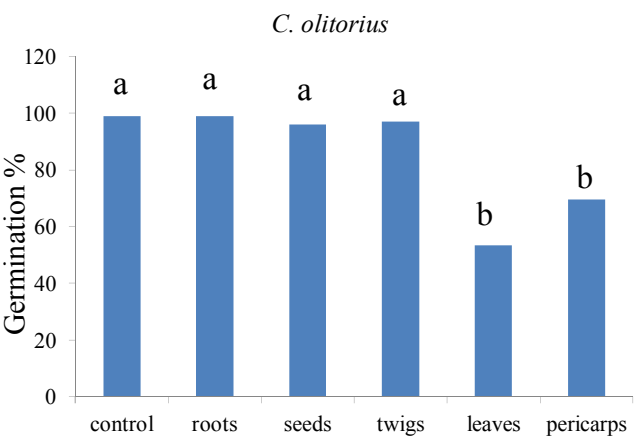

Fig. 6. Effects of aqueous extract of $R$. communis tissues on the germination of $C$. olitorius

The presence of phenolic compounds could be the cause of reduction in germination and growth of seedlings [26]. Indeed, $R$. communis is rich in phenol [16,30]; the monoterpenoids (1,8-cinole, camphor and $\alpha$-pinene) and sesquiterpenoids ( $\beta$ caryophyllene), gallic acid, quercetin, gentisic acid, rutin, epicatechin and ellagic acid are the major phenolic compounds isolated from leaves. Indole-3-acetic acid has been extracted from the

Table 1. Average root length $(\mathrm{mm})$ after 3 days for each species treated with aqueous extract of different organ of $R$. communis

\begin{tabular}{lllllll}
\hline Species & M. sativa & C. olitorius & H. vulgare & C. arietinum & $\begin{array}{l}\text { T. foenum- } \\
\text { graecum }\end{array}$ & L. culinaris \\
\hline Control & $66.9 \pm 7.6$ & $69.4 \pm 12.4$ & $74.5 \pm 10.3$ & $81.1 \pm 17.1$ & $83.6 \pm 14.4$ & $38.9 \pm 8.1$ \\
Root & $28.2 \pm 4.4$ & $36.2 \pm 5.7$ & $21.6 \pm 4.5$ & $27.9 \pm 4.1$ & $29 \pm 3.3$ & $22.4 \pm 2.6$ \\
Seed & $14.6 \pm 3.4$ & $27.6 \pm 4.9$ & $15.3 \pm 4.1$ & $23.7 \pm 5.4$ & $25.6 \pm 4.5$ & $16.9 \pm 3.6$ \\
Twig & $18.9 \pm 4.6$ & $19.1 \pm 3.7$ & $25.1 \pm 5.4$ & $14.3 \pm 3.9$ & $17.2 \pm 2.43$ & $21.8 \pm 5.7$ \\
Leaf & $4.5 \pm 0.7$ & $4 \pm 1.1$ & $4.2 \pm 0.94$ & $8 \pm 1.1$ & $3.5 \pm 0.7$ & $3 \pm 0.5$ \\
Pericarp & $3.2 \pm 1.5$ & $6.3 \pm 1.4$ & $6.3 \pm 2.3$ & $8.5 \pm 2.9$ & $6.5 \pm 0.7$ & 0 \\
\hline
\end{tabular}


roots [17,31]. Phenolic allelochemicals can lead to increased cell membrane permeability inhibiting plants from absorbing nutrients from the surroundings and affecting the normal growth of plants [2]. Also, the phenolic allelochemicals could inhibit cell division and alter the ultrastructure of the cells [32].

\section{CONCLUSION}

Our results show a very high allelopathic effect of the aqueous extracts from Ricinus communis, an spontaneous and frequent species in agricultural land in Tunisia, on germination and root growth of six crops $(H$. vulgare, $M$. sativa, $C$. olitorius, $T$. foenum-graecum, L. culinaris and C. arietinum). This inhibitory effect is increasingly high for two organs of the plant: the sheet and the pericarp, and depends on the species considered.

\section{COMPETING INTERESTS}

Authors have declared that no competing interests exist.

\section{REFERENCES}

1. Monem R, Mirsharifi SM, Mirtaheri SM. Evaluation Allelopathic Effects of barley shoot aqueous extract on germination, seedling growth, cell membrance permeability and malondialdehyde content of corn weeds. Advances in Environmental Biology. 2012;6(9):2490-495.

2. Li ZH, Wang $Q$, Ruan X, Pan CD, Jiang DA. Phenolics and plant allelopathy. Molecules, 2010;15:8933-952.

DOI:10.3390/molecules15128933.

3. Qasem JR. Allelopathy importance, field application and potential role in pest management: A review. Journal of Agricultural Science and Technology. 2010;4, N6, serial N³1:104-20.

4. Ladda PL, Kamthane RB. Ricinus Communis (Castor): An overview. Int. J. of Res. in Pharmacology \& Pharmacotherapeutics. 2014;3(2):136-44.

5. Enan M, Fawzi N, Al-Deeb M, Amiri K. DNA Barcoding of Ricinus communis from Different Geographical Origin by Using Chloroplast matK and Internal Transcribed
Spacers. American Journal of Plant Sciences. 2012;3:1304-310.

Available:http://dx.doi.org/10.4236/ajps.20 $\underline{12.39157}$

6. Salihu BZ, Gana AK, Apuyor BO. Castor oil plant (Ricinus communis L.): Botany, ecology and uses. International Journal of Science and Research. 2014;3(5):1333341.

7. Goodarzi F, Darvishzadeh R, Hassani A, Hassanzaeh A. Study on genetic variation in Iranian castor bean (Ricinus communis L.) accessions using multivariate statistical techniques. Journal of Medicinal Plants Research. 2012;6(7):1160-167.

8. Bajay MM, Pinheiro JB, Batista CEA. Marcia Barreto Medeiros Nobrega MBM, Zucch MI. Development and characterization of microsatellite markers for castor (Ricinus communis L.), an important oleaginous species for biodiesel production. Conservation Genet Resour; 2009. DOI 10.1007/s12686-009-9058-z.

9. Chan AP, Crabtree J, Zhao Q, Lorenzi $H$, Orvis J, Puiu D, Melake-Berhan A, Jones KM, Redman J, Chen G, Cahoon EB, Gedil M, Stanke M, Haas MJ, Wortman JR, Fraser-Liggett CM, Ravel J, Rabinowicz PD. Draft genome sequence of the oilseed species Ricinus communis. Nature Biotechnology. 2010;28(9):951-59.

10. Jeong GT, Park DH. Optimization of biodiesel production from castor oil using response surface methodology. Appl. Biochem. Biotechnol. 2009;156:431-41.

11. Marín MJG, García FP. Obtaining and characterization of biodiesel from castor oil (Ricinus communis) and sunflower (Helianthus annuus) grown in tabasco, Mexico. International Journal of Applied Science and Technology. 2012;2(9):5874.

12. Witt T. Performance of five castor (Ricinus communis L.) genotypes in geographically diverse environments of North America. Thesis, Texas Tech University. 2014;46.

13. Rana M, Dhamija H, Prashar B, Sharma S. Ricinus communis L.- A review. International Journal of Pharm Tech Research. 2012;4(4):1706-711.

14. Taur DJ, Patil RY. Antiasthmatic activity of Ricinus communis L. roots. Asian Pacific Journal of Tropical Biomedicine. 2011; 1(1):13-16. 
15. Ben Salem AN, Zyed R, Lassoued MA, Nidhal S, Sfar S, Mahjoub A. Plant-derived nanoparticles enhance antiviral activity against coxsakievirus b3 by acting on virus particles and verocells. Digest Journal of Nanomaterials and Biostructures. 2012; 7(2):737-44.

16. Iqbal J, Zaib S, Farooq U, Khan A, Bibi I, Suleman S. Antioxidant, Antimicrobial, and Free Radical Scavenging Potential of Aerial Parts of Periploca aphylla and Ricinus communis. Pharmacology. 2012;6. DOI:10.5402/2012/563267.

17. Jena J, Gupta A K. Ricinus communis Linn: A phytopharmacological review. Int J Pharm Pharm Sci. 2012;4(4):25-9.

18. Singh V, Sharma S, Dhar KL, Kalia AN. Activity guided isolation of antiinflammatory compound / fraction from root of Ricinus communis Linn. International Journal of Pharm Tech Research. 2013; 5(3):1142-149.

19. Kadri A, Gharsallah N, Damak M, Gdoura R. Chemical compodition and In vitro antioxidant properties of essential oil if Ricinus communis L. Journal of Medicinal Plants Research. 2011;5(8):1466-470.

20. Zarai Z, Ben Chobba I, Ben Mansour R, Békir A, Gharsallah N, Kadri A. Essential oil of the leaves of Ricinus communis L.: In vitro cytotoxicity and antimicrobial properties. Lipids in Health and Disease. 2012;11:102. DOI:10.1186/1476-511X-11102.

21. Nekonam MS, Razmjoo J, Sharifnabi B. Karimmojeni H. Assessment of allelopathic plants for their herbicidal potential against field bindweed (Convolvulus arvensis). Australian Journal of Crop Science. 2013; 7(11):1654-660.

22. Seyyedi M, Moghaddam PR, Shahriari R, Zad MA, Eyshi Rezaei E. Allelopathic potential of sunflower and caster bean on germination properties of dodder (Cuscuta compestris). African Journal of Agricultural Research. 2013;8(7):601-07.

DOI:10.5897/AJAR12.2136.

23. Mohammadi A, Mohammadi N, Alijani AM, Peykarestan B. Evaluation of allelopathic potential of two plant species, caster (Ricinus communis) and neem (Azadirachta indica. A. Juss) against seed germination and seedling growth of lentil (Lens culinaris medik). International
Journal of Agriculture and Crop Sciences. 2014;4(8):54-7.

24. Nekonam MS, Razmjoo J, Kraimmojeni H, Sharifnabi B, Amini $H$, Bahrami $F$. Assessment of some medicinal plants for their allelopathic potential against redroot pigweed (Amaranthus retroflexus). Journal of Plant Protection Research. 2014;54(1): 90-5.

25. Mominul Islam AKM, Kato-Noguchi $H$. Allelopathic prospective of Ricinus communis and Jatropha curcas for biocontrol of weeds. Acta Agriculturea Scandinavica, Section B- Soil \& Plant Science. 2013;63(8):731-39.

DOI:10.1080/09064710.2013.865073.

26. Aburge S, Quashie-Sam SJQ. Evaluating the allelopathic effect of Jatropha curcas aqueous extract on germination, radical, and plumule length of crops. Int. J. Agric. Biol. 2010;12:769-72.

27. Nadaletti WC, Bariccatti, RA, Santos RF, Melegari de Souza SN, Antonelli J, Cremonez PA, de Rossi E, Tomassoni F. Influence of leaf extract of Jatropha curcas on initial growth of cauliflower (Brassica oleracea var. botrytis). Afr. J. Agric. Res. 2014;9(4):521- 26.

28. Saadaoui E, Ghazel N, Ben Romdhane Ch, Tlili N, Khaldi A. Allelopathic effects of aqueous extracts of Eucalyptus occidentalis Endl., Acacia ampliceps Maslin and Prosopis juliflora L. on the germination of three species cultivated in the South of Tunisia. Tunisian Journal of Plant Protection. 2014;9(1):11-6.

29. Siddiqui S, Ruchi Yadav R, Yadav K, Wani FA, Meghvansi MK, Sharma S, Jabeen F. Allelopathic potentialities of different concentration of aqueous leaf extracts of some arable trees on germination and radicle growth of Cicer arietinum var. - C235. Global Journal of Molecular Sciences. 2009;4(2):91-5

30. Vimala Y, Ahalavat KA, Gupta MK. Physico-chemical interpretation of allelopathic interaction of vetiver with two non-edible oil yielding fence plants. J. Exp. Bot. 2005;2:141-50.

31. Darmanin S, Wismaver PS, Camillerri Podesta MT, Micallef MJ, Buhagiar JA. An extract from Ricinus communis $\mathrm{L}$. leaves possesses cytotoxic properties and induces apoptosis in SKMEL- 28 human 
melanoma cells. Nat Prod Res. 2009; 23(6):561-71.

Allelopathic effects of Sonchus oleraceus L. on the germination and seedling growth

32. Gomaa NH, Hassan MO, Fahmy GM, González L, Hammouda O, Atteya AM. of crop and weed species. Acta Bot. Bras. 2014;28(3):408-16.

(C) 2015 Saadaoui et al.; This is an Open Access article distributed under the terms of the Creative Commons Attribution License (http://creativecommons.org/licenses/by/4.0), which permits unrestricted use, distribution, and reproduction in any medium, provided the original work is properly cited.

Peer-review history:

The peer review history for this paper can be accessed here: http://www.sciencedomain.org/review-history.php?iid=1096\&id=24\&aid=9317 